A R C HIWA，B IB LIOTEKI

I MUZEA KOŚCIELNE 111 (2019)

https://doi.org.10.31743/abmk.2019.111.16

PIOTR SZKUTNIK* - ŁÓDŹ

\title{
POCZĄTKI TWORZENIA KOMPOZYCJI Z KWIATÓW NA TRASIE PROCESJI BOŻEGO CIAŁA W SPYCIMIERZU
}

\begin{abstract}
Streszczenie
Uroczystości Bożego Ciała zapoczątkowane w Kościele katolickim w XIII wieku stały się okazją do oddania czci Najświętszemu Sakramentowi. Święto z czasem zostało wzbogacone o zewnętrzną formę kultu. W leżącej nad rzeką Wartą wsi Spycimierz formy adoracji hostii rozwinięto w postaci rozbudowanej oprawy wizualnej. Trasa procesji Bożego Ciała poza typowym wystrojem ołtarzy została w całości przyozdobiona kompozycjami z kwiatów, którymi wyłożono środkowy pas drogi we wsi. Tradycja tworzenia kwietnych kobierców według przekazów ma sięgać okresu napoleońskiego. Niewątpliwie istniała już przed drugą wojną światową, a pierwsze źródła o niej informujące pochodzą z 1957 roku.
\end{abstract}

Słowa kluczowe: historia Kościoła katolickiego; XIII-XXI w.; Boże Ciało; Spycimierz; procesje; zwyczaje ludowe; florystyka

Celem niniejszego artykułu jest przedstawienie początków tworzenia kompozycji z kwiatów na drodze procesji podczas święta Bożego Ciała w Spycimierzu.

\section{Zarys historii Bożego Ciala}

Wprowadzenie świąt Bożego Ciała nastąpiło pod wpływem objawień św. Julianny z Cornillon mających miejsce od 1209 roku. Biskup Robert z Thourotte ustanowił w 1246 roku tę uroczystość dla diecezji Liège. W 1252 roku legat papieski rozszerzył jąna Germanię. PapieżUrban IV bullą Transiturus w 1264 rokuustanowił to święto dla całego Kościoła. Bullę tę potwierdził dopiero papież Klemens V,

* Piotr Szkutnik - dr historii; adiunkt w Katedrze Historii Uniwersytetu Łódzkiego; e-mail: pszkutnik@poczta.onet.pl

https://orcid.org/0000-0001-6086-2655 
publikując ją w 1317 roku. Przypisane do tego święta odpusty przyczyniły się do rozwoju kultu i różnych form adoracji Najświętszego Sakramentu. Wierni przeświadczeni o cudownych mocach hostii chętnie uczestniczyli w celebrujących ją uroczystościach. W XIV wieku pojawiło się naczynie liturgiczne nazywane monstrancją. Zastosowanie w nim kryształu górskiego umożliwiło pokazywanie w okienku pojedynczego opłatka. W Polsce obchody Bożego Ciała zostały wprowadzone w diecezji krakowskiej przez biskupa Nankera. Po raz pierwszy są wzmiankowane w 1320 roku, a stały się powszechne w latach 1420-1440 ${ }^{1}$. Najwcześniejsze procesje podczas tego święta odbyły się w Kolonii w latach 1265-1275. W Polsce funkcjonowały już XV wieku², gdy przyjął się zwyczaj śpiewania Ewangelii przy czterech ołtarzach. Sobór Trydencki w XVI wieku podtrzymał doktrynę transsubstancjacji i ceremonialnych procesji. Procesje odbywające się w XVIII wieku, opisywane przez ks. Jędrzeja Kitowicza, były okazją do zaprezentowania różnych popisów, m.in. wymachiwania chorągwiami i oddawania salw z broni palnej ${ }^{3}$. Na ziemiach polskich od okresu zaborów uczestnictwo $\mathrm{w}$ procesji wiązało się $\mathrm{z}$ manifestacją wyrażającą przynależność narodową i patriotyczną postawę wiernych ${ }^{4}$. Dekorowanie trasy, po której podczas procesji niesiony jest pod baldachimem Najświętszy Sakrament, stanowi przejaw czci parafian dla tej cząstki Bożej.

\section{Zarys historii Spycimierza}

Spycimierz to mała wieś położona w dolinie rzeki Warty, w gminie Uniejów ${ }^{5}$, na zachodnich rubieżach województwa łódzkiego, przy granicy z województwem wielkopolskim. Około $500 \mathrm{~m}$ na północny wschód od wsi znajduje się grodzisko stożkowate o wysokości ok. $2 \mathrm{~m}$ otoczone wałem, gdzie znajdował się gród kasztelański ${ }^{6}$. Nazwa miejscowości była różnie zapisywana i nawet obecnie jest różnie wymawiana jako Śpicimierz, Spicimierz, Spicymierz 7 . Toponim

${ }^{1}$ R. Hołda, Boże Ciało. Święto, ceremonia i performans, „Journal of Urban Ethnology”, 11 (2013) s. 66-67.

${ }^{2}$ W Krakowie procesje odbywały się w XV wieku, jednak dopiero z początku XVI wieku pochodzą teksty liturgiczne przewidziane do wykorzystania podczas tego nabożeństwa. Zob.: S. Fedorowicz, Procesje parafialne i klasztorne w oktawie Bożego Ciała w XIX-wiecznym Krakowie (17951918), „Nasza Przeszłość”, 115-116 (2011) s. 219.

${ }^{3}$ M. Bogunia-Borowska, O zwyczajach pobożnych. Groby w Wielki Piatek i procesje w Boże Ciało. Antropologia zwyczajów religijnych w społeczeństwie polskim, „Societas Communitas”, 17 (2014) nr 1, s. 231-233.

${ }^{4}$ Z. Zalewski, Boże Ciało I. Liturgia, w: Encyklopedia Katolicka, t. 2, red. F. Gryglewicz, Lublin 1976, kol. 861-862. M. Dyoniziak, Boże Ciało w Spycimierzu - w hołdzie Janowi Pawłowi II, Bydgoszcz 2005, s. 13.

${ }^{5}$ P. Maluśkiewicz, Ziemia konińska. Przewodnik turystyczny, Konin 2002, s. 155.

${ }^{6}$ P. Maluśkiewicz, Słownik krajoznawczy Wielkopolski, Warszawa 1992, s. 252.

${ }^{7}$ M. Komajda, Wieś kwiatami malowana, „W Uniejowie”, 2 (2000) s. 12. 
pochodzi od słowiańskiego imienia Spycimir. W czasach Władysława Hermana Spicymir, protoplasta rodu Leliwitów, osadę nazwaną na jego cześć miał nadać arcybiskupom gnieźnieńskim ${ }^{8}$.

Pierwsze wzmianki ${ }^{9}$ dotyczące Spycimierza znajdują się w kronice Galla Anonima z przełomu 1106-1107 roku, gdy ks. Bolesław Krzywousty uwięził tu arcybiskupa gnieźnieńskiego Marcina. Kolejny przekaz z 1108 roku dokumentuje istnienie w tym grodzie kościoła, zapewne parafialnego. Gród 20 września 1331 roku spalili Krzyżacy. W 1347 roku został nadany arcybiskupowi gnieźnieńskiemu Jarosławowi Bogorii ze Skotnik. Parafia nosiła wezwanie św. Krzyża, pierwszy raz wspomniane w 1423 roku. Postanowieniem arcybiskupa Zbigniewa Oleśnickiego z 28 kwietnia 1491 roku parafia została wcielona do uposażenia kolegium mansjonarzy funkcjonującego przy kolegiacie w Uniejowie. Drewniany kościół parafialny zbudowany po zniszczeniach w XIV wieku był zapewne tą samą świątynią, którą odnotowano w wizytacji z 1712 roku. W 1784 roku został zastąpiony przez nowy, również drewniany, kościół (rozebrany przez Niemców w 1943 roku $^{10}$ ). Parafia składała się z trzech miejscowości: Spycimierza, Człopów i Zieleni. W 1728 roku liczyła ok. 200 wiernych, na początku XIX wieku już ok. 300. W 1818 roku, w wyniku reorganizacji administracji kościelnej, parafia została odłączona od archidiecezji gnieźnieńskiej i włączona do diecezji kujawskokaliskiej (włocławskiej). Około 1865 roku zarząd parafią przestali sprawować duchowni z Uniejowa. Spycimierz otrzymał własnych proboszczów. W 1890 roku Spycimierz wraz z osadą Malczew liczył 535 mieszkańców. W latach 1945-1946 zbudowano kolejny, czwarty kościół drewniany. Zastąpił go pierwszy murowany, który powstał w latach 1986-1992 ${ }^{11}$. W 1971 roku wieś strawił pożar, niszcząc 63 zabudowania. Miejscowość została odbudowana ${ }^{12}$. W 1994 roku parafia Spycimierz liczyła 702 wiernych $^{13}$. W 2011 roku składała się z wsi Człopki, Człopy, Leśnik, Spycimierz, Spycimierz Kolonia, Zielenn ${ }^{14}$.

\section{Boże Ciało w Spycimierzu}

Obyczaj tworzenia kwietnych kompozycji na drodze przemarszu procesji podczas uroczystości Bożego Ciała w Spycimierzu jest wyjątkowy w skali całego

\footnotetext{
${ }^{8}$ W. Kujawski, Śpicimierz, „Ład Boży”, (1992) nr 19, s. 6.

${ }^{9}$ Gród pod nazwą Zbuczmir wymienia tzw. falsyfikat mogileński datowany na $1065 \mathrm{r}$. Zob.: Archiwum Diecezjalne we Włocławku (dalej: ADWł), Prace dyplomowe, sygn. 56, ks. Kujawski, Śpicimierz, s. 1.

${ }^{10}$ H. Klata, Było - nie minęto. Gawęda o Śpicimierzu, „Ład Boży” dodatek do „Niedziela”, (2000) nr 16, s. 3.

${ }^{11}$ Uniejowskie strony. Karty z przeszłości odległej, nieznanej i bliskiej gminy Uniejów, red. J. Szymczak, Łódź 2008, s. 123-136.

${ }_{12}$ W. Winnicki, Jubileusz OSP w Spycimierzu, „W Uniejowie”, (2008) nr 35, s. 23.

${ }^{13}$ W. Krzywański, Boże Ciało w Śpicimierzu, w: Kalendarz Rolników 1994, red. E. Marciniak, Włocławek 1994, s. 94.

${ }^{14}$ Rocznik diecezji włocławskiej 2011, red. A. Niemira, Włocławek 2011, s. 962.
} 
$\mathrm{kraju}^{15}$. Niektórzy obserwatorzy twierdzą, że tworzone w pobliskich parafiach podobne dywany wynikają jedynie z naśladownictwa tradycji wywodzącej się ze Spycimierza ${ }^{16}$.

Odbywające się w tej nadwarciańskiej wsi uroczystości kościelne związane z Bożym Ciałem już w okresie PRL wzbudzały zainteresowanie mediów. W 1988 roku Andrzej Moś zrealizował tam reportaż filmowy (barwny) pt. Wieś kwiatami malowana o układanych na drodze procesji barwnych kompozycjach z kwiatów ${ }^{17}$.

Przygotowania do stworzenia kwiatowej oprawy święta Bożego Ciała trwają we wsi kilka dni. Od poniedziałku, bezpośrednio przed czwartkową uroczystością, zrywane są na okolicznych łąkach chabry, rumianki, wrotycz, dzikie róże ${ }^{18}$, łubiny, jaskry, polne maki, buldynezy, paprocie, jaśminy i inne polne kwiaty ${ }^{19}$, gałązki drzew i krzewów, trawy, liście ${ }^{20}$, kora. Na kobierce są przeznaczane setki kilogramów kwiatów ${ }^{21}$. W przygotowaniach biorą udział mieszkańcy wsi oraz ich krewni mieszkający w całym $\mathrm{kraju}^{22}$. Poza kwiatami polnymi i ogrodowymi, w latach 90. zaczęto wykorzystywać również szklarniowe. Dekorowanie rozpoczyna obsadzanie drogi procesji wczesnym rankiem ściętymi brzózkami ${ }^{23}$. Następnie na ulicach tworzone są kobierce z kwiatów, po których o godzinie 17 przechodzi procesja. Gdy we wsi nie było jeszcze nawierzchni ulic wykonanej z kostki brukowej i asfaltu, wzory wysypywano początkowo piaskiem, a następnie wypełniano przestrzenie kolorowymi kwiatami ${ }^{24}$.

Zwyczajowo właściciel posesji przylegającej do danego odcinka trasy procesji jest odpowiedzialny za jej udekorowanie ${ }^{25}$. Z kwiatów są komponowane na ulicach bryły geometryczne, ornamenty roślinne, symbole religijne: baranki, hostie, serca ${ }^{26}$. Współcześni twórcy kwietnych kompozycji twierdzą, że stopień ukwiecenia dywanu zależy od dostępności płatków kwiatów w danym roku, jak również deszczowej aury, ponieważ mokre płatki źle się przechowują ${ }^{27}$.

${ }^{15}$ Mimo iż w wielu miejscowościach ma on przebieg wyjątkowo uroczysty. Zob. np.: J. Śmigielska, Święto Bożego Ciała w Łowiczu, „Societas Communitas”, 2 (2010) s. 255.

${ }^{16} \mathrm{~W}$ parafii Piekary układane są dywany kwietne długości ok. $200 \mathrm{~m}$, w Poddębicach są tworzone w pobliżu ołtarzy procesyjnych. Zob.: A. Głaz, Boże Ciało w Spycimierzu, „Kronika Wielkopolski”, 4 (2005) s. 119.

${ }^{17}$ M. Jabłoński, Z cyklu „,Moja wieś” Spicymierz, „Echo Turku”, (1993) nr 6, s. 6.

${ }^{18}$ J. Jackowski, J. Iwanicka, Dywany w Śpicimierzu, „Gazeta Sołecka”, (1996) nr 10, s. 14.

${ }^{19}$ Głaz, Boże Ciało w Spycimierzu, s. 119-120.

${ }^{20}$ D. Lasociński, Po kwietnych dywanach, dodatek do „Turystyka”, (2005) nr 117, s. 7

${ }^{21}$ K. Kaniecki, Kolorowy Śpicimierz, „Nad Wartą”, (2002) nr 23, s.13.

${ }^{22}$ Po kwiatowych dywanach, „Głos Wielkopolski”, (2001) nr 138, s. 15.

${ }^{23}$ S. Nowicki, Kwietne Boże Ciało, „Ład Boży” dodatek do „Niedziela”, (2001) nr 28, s. 2.

${ }^{24}$ A. Micuła, Spicimierz. Dywany kwiatowe, „Tele Tydzień”, (2004) nr 23, s. 42.

${ }^{25}$ Autor niniejszego artykułu zaproponował w 2017 roku stworzenie fotograficznej dokumentacji uwieczniającej twórców danego odcinka ukwieconego kobierca wraz z ich dziełem.

${ }^{26}$ K. Chojnacki, Kwietna droga, „Kwietnik”, (1998) nr 6, s. 29.

${ }^{27}$ K. Kaniecki, Dywany zrywane na miarę, „Dziennik Łódzki”, 8 VI 2007, s. 22. 
W zależności od okoliczności pojawiają się wzory nawiązujące do ważnych w danym roku wydarzeń, np. w 2000 roku była to symbolika Roku Jubileuszowego ${ }^{28}$. W 2007 roku obchodom 900-lecia Spycimierza towarzyszyły dodatkowe atrakcje (koncert organowy, inscenizacje historyczne) ${ }^{29}$. W uroczystościach często uczestniczą biskupi ${ }^{30}$. Według różnych przywoływanych w treści przekazów prasowych ukwiecona trasa $\mathrm{w}$ ostatnim ćwierćwieczu mierzyła od 1 do $2 \mathrm{~km}$ długości i około $2 \mathrm{~m}$ szerokości. W ostatnich latach wydaje się ona być nieco węższa niż w odległych dekadach. Pozostawienie po bokach drogi szerszych, nieukwieconych pasów umożliwia bowiem przemieszczanie się po obu stronach tłumu turystów i wiernych oglądającego to dzieło sztuki ludowej. Rozmiary kobierca dopasowano zatem ze względów praktycznych do wzrastającej liczby oglądających.

\section{Początki kwietnych kobierców w Spycimierzu}

Najwcześniejsze precyzyjne informacje ${ }^{31}$ dotyczące przystrajania trasy procesji pochodzą z kroniki parafialnej Spycimierza z czerwca 1957 roku, gdzie wspomniano, ,że tradycyjnym już zwyczajem trasa procesji bywa pięknie dekorowana". Obok zamieszczono również najstarsze znane fotografie z ozdobionej drogi procesji sprzed ponad 60 lat $^{32}$. Na fotografiach tych widać, że trasa miała przede wszystkim wytyczone liniami, zapewne usypanymi z piasku, podłużne krawędzie, przy czym wzdłuż dwóch zewnętrznych linii biegły również cztery wewnętrzne na jednym z odcinków, a na drugim, wewnątrz wytyczonej liniami zewnętrznymi trasy, znajdowały się białe kształty geometryczne. Całość prezentowała sięznaczenie bardziej ubogo niż w późniejszych dekadach. Jak podaje następna karta kroniki, uroczystość ta była połączona z wizytacją biskupią 24-25 czerwca 1957 roku, podczas której na drodze we wsi „ułożono różnokolorowe wzory z kwiatów" oraz wzniesiono 8 przystrojonych bram. Według późniejszych przekazów z lat 90. skomplikowane wzory z kwiatów zaczęto tworzyć właśnie w latach 50. XX wieku, gdy wcześniej tworzono je głównie z piasku i niewielkiej ilości kwiatów ${ }^{33}$. Wcześniej jedynie sypano kwiaty dobierając kolorami ${ }^{34}$.

${ }^{28}$ S. Nowicki, Boże Ciało w Śpicimierzu, „Ład Boży” dodatek do „Niedziela”, (2000) nr 29, s. 3.

${ }^{29}$ Kwietne dywany na chwate Panu, „Echo Turku”, (2007) nr 24, s. 3.

${ }^{30}$ W 1999 roku np. nuncjusz apostolski abp Józef Kowalczyk i ordynariusz włocławski bp Bronisław Dembowski. Zob.: Spicimierz. Nie zwykte święto, „Echo Turku”, (1999) nr 24, s. 3.

${ }^{31} \mathrm{~W}$ aktach kurii włocławskiej z okresu między wojennego (1922-1938) nie odnaleziono wzmianki o tym zwyczaju. Zob.: ADWł, Archiwum Kurii Diecezjalnej we Włocławku, Akta parafii Śpicimierz, sygn. AKDWł par. 203; jak również w protokole wizytacyjnym parafii Śpicimierz z 1838 r. Zob.: ADWł, Akta diecezji kujawsko-kaliskiej, Akta wizytacji, sygn. 17 (209).

${ }^{32}$ Do najstarszych fotografii, na których uwieczniono procesje Bożego Ciała, należą zdjęcia wykonane przez Karola Beyera w 1863 roku w Warszawie. Zob.: W. Przybyszewski, Procesje Bozego Ciała $w$ Warszawie $w$ latach 1827-1863 $w$ relacjach prasowych, malarstwie i na fotografiach Karola Beyera, „Almanach Warszawy”, 9 (2015) s. 222-223.

${ }^{33}$ Chojnacki, Kwietna droga, s. 29.

${ }^{34}$ Micuła, Spicimierz, s. 42. 
W czerwcu 1958 roku, w związku z przygotowaniem trasy procesji z okazji Bożego Ciała, jak podaje kronika parafialna, „cały Śpicimierz od najmniejszego do najstarszego od świtu przygotowują z dróg principalnych wspaniałe aleje wysadzane drzewami, ozdobione bramami tryumfalnemi i wspaniałemi dywanami z żywych i rozmaitych kwiatów". Na czarno-białych fotografiach z tego roku widać podłużny wytyczony pas na którym znajdowały się również 4 linie, inne kompozycje są mniej rozpoznawalne ${ }^{35}$.

Pierwsza zachowana kolorowa fotografia z procesji Bożego Ciała pochodzi z 1976 roku. Uwieczniono na niej orkiestrę przechodząca po przyozdobionej kolorowymi kwiatami drodze. Udekorowana droga stanowiła wówczas pas szerokości ok. 2,5 m na którym mieściły się 4 maszerujące obok siebie osoby. Wzory kwietne nie są zbyt dobrze widoczne, stanowią kompozycje koliste, gwiaździste. Widoczne są kolory fioletowy, różowy, żółty, biały, zielony. Kompozycje nie są gęsto usiane płatkami kwiatów, ich podłoże nie odróżnia się zbytnio kolorystycznie od ciemnej wydeptanej po bokach ziemi stanowiącej podłoże drogi gruntowej po środku której usypano kobierzec ${ }^{36}$.

Podczas Bożego Ciała 25 czerwca 1978 roku, jak zaznaczył w kronice proboszcz, trasa procesji „wg wieloletniej tradycji jest przystrojona dywanem z kwiatów. Jest to znak czci Eucharystii spotykany jedynie w okolicy Spicimierza". Zbudowano wówczas 4 ołtarze. Trasa przyozdobiona była również wytyczona pasami zewnętrznymi. Dnia 14 czerwca 1979 roku ze względu na ulewę procesja nie odbyła się.

Kolejne kolorowe fotografie trasy procesji pochodzą z Bożego Ciała z 6 czerwca 1980 roku, na których widać zygzakowate, półkoliste, ułożone w formie kwiatów czy kielicha $\mathrm{z}$ napisem JHS kompozycje na wytyczonym pasie drogi. Ówczesna trasa procesji biegła również w pobliżu starego koryta rzeki Warty. Proboszcz relacjonował, iż

uroczystość Bożego Ciała, jak każdego roku ściągnęła wielu wiernych z okolic: Konina, Poddębic, Turku, Koła oraz najbliższych parafii. Parafianie śpicimierscy starannie przygotowują trasę procesji eucharystycznej, która ma $1,5 \mathrm{~km}$. Środkiem ulicy sypany jest dywan z żywych kwiatów, które zbierają całe rodziny wiele dni przed uroczystością.

Na kwietnych dywanach z 16 czerwca 1981 roku pojawiają się m.in. serce, romby, półkola; 10 czerwca 1982 roku były to wzory w postaci kwiatów i półkola. Kronika parafialna prezentuje też zdjęcia z 2 czerwca 1983 roku oraz kolejne z 6 czerwca 1996 roku $^{37}$.

W świetle ustnych przekazów mieszkańców trudno ustalić czas powstania zwyczaju tworzenia przystrojonej trasy procesji podczas Bożego Ciała. Publikacje dotyczące tej tradycji opisują zwyczaj szerzej dopiero od lat 90 . XX wieku, gdy stał się bardziej znany w kraju.

${ }^{35}$ Kancelaria parafii rzymsko-katolickiej w Spycimierzu (dalej: KP Spycimierz), Kronika parafii Spycimierz 1945-1960, k. nlb.

${ }^{36}$ Archiwum rodzinne Marii Pełki ze Spycimierza.

${ }^{37}$ KP Spycimierz, Kronika parafii Spycimierz 1977-1984, 1992-1996, k. nlb. 
Goszcząca w Spycimierzu w latach 1994-1996 etnograf z Muzeum Okręgowego w Sieradzu Bogna Ciesielska-Szynal przeprowadziła wywiady z kilkunastoma mieszkańcami $\mathrm{wsi}^{38}$. Żaden $\mathrm{z}$ ówczesnych respondentów nie potrafił precyzyjnie określić czasu powstania tradycji. Mieszkańcy wspominali wówczas o dawnym zarzuconym 20 lat wcześniej zwyczaju strojenia bram przez każda wioskę z parafii. Opowiadano, że w okresie międzywojennym wzdłuż trasy procesji usypywano wzory z piasku. Za każdy odcinek trasy odpowiadała dana rodzina, co powodowało współzawodnictwo parafian starających się jak najokazalej skomponować własną część drogi.

$Z$ relacji wynika, że duży wpływ na uregulowanie i wzbogacenie kompozycji kwiatowych tras miał ks. Wojciech Krzywański (duszpasterz parafii w latach 1977-1993). Jeden z rozmówców twierdził, że zwyczaj układania kwiatów funkcjonował już przed wojną, natomiast inny konstatował, że trwa co najmniej 20 lat od czasów W. Krzywańskiego, gdy wszyscy we wsi zaczęli te kwiaty układać. Etnografka napisała, że prawdopodobnie w latach 50. i 60. XX wieku trasę posypywano mieszanką kwiatów. Brzegi obkładano liśćmi kasztana, a w środku sypano kwiaty w różnych kolorach ${ }^{39}$.

Wieloletni duszpasterz parafii Spycimierz ks. W. Krzywański w swoim artykule z 1994 roku pisał, że tradycja przygotowywania ww. zdobionej trasy sięga końca XIX wieku. Początkowo do wystroju używano żółtego piasku i gałęzi drzew. W okresie międzywojennym układano kompozycje z kwiatów i ozdobnych krzewów. Po drugiej wojnie światowej powstawały coraz bardziej różnorodne kształtem i kolorem kwietne dywany ${ }^{40}$. W wywiadzie $\mathrm{z}$ autorem wspominał jednak, że tradycja strojenia trasy procesji może sięgać czasów napoleońskich ${ }^{41}$. Podobnie wypowiadał się już wcześniej. Zwyczaj być może przybył razem z wojskami Napoleona. Żołnierze mogli widzieć podobne kobierce układane na drogach Hiszpanii ${ }^{42}$. W swoim artykule Andrzej Głaz zamieszcił opinię, w której zwyczaj tworzenia kobierców łączył z możliwością przeniesienia tradycji przez mężczyzn wracających z służby w wojsku napoleońskim, którzy tego typu oprawę święta mogli zaobserwować na południu Europy, w kręgu kultury iberyjskiej, gdzie jest praktykowany. Według tego autora mieszkańcy genezę zwyczaju sytuowali na początku XIX wieku. ${ }^{43}$ Jerzy Sobczak również wiąże początek tradycji zdobienia

${ }^{38}$ Rękopisy wywiadów prawdopodobnie zaginęły po śmierci jej autorki. Mimo poszukiwań podczas kwerendy 18 maja 2017 roku przeprowadzonej w dziale etnografii Muzeum Okręgowego w Sieradzu relacje nie zostały odnalezione.

${ }^{39}$ B. Ciesielska-Szynal, Dekoracje kwiatowe trasy procesji Bożego Ciała w Spicimie$r z u$, „Sieradzki Rocznik Muzealny”, 10 (1995/1996), s. 33.

${ }^{40}$ Krzywański, Boże Ciało, s. 96-97.

${ }^{41}$ Wywiad autora z ks. W. Krzywańskim przeprowadzony 16 maja 2017 roku we Włocławku-Michelinie.

${ }^{42}$ B. Radecka, Od ottarza do oltarza po kwietnym kobiercu, „Turystyka”, dodatek do „Turystyka", (1999) nr 124, s. 6.

${ }^{43}$ Głaz, Boże Ciało, s. 119. 
trasy procesji z wojskami Napoleona na początku XIX wieku. Uważał, że początkowo używano żółtego piasku i gałęzi drzew, a w okresie międzywojennym zaczęto używać kwiatów ${ }^{44}$.

Jak dotąd nie odnaleziono poświadczenia funkcjonowania omawianych praktyk w XIX wieku. Mirosława Klimczak w swojej pracy magisterskiej, obronionej w 1988 roku, pisze, że o zwyczaju układania zdobionej trasy podczas Bożego Ciała nie wspomina etnograf i folklorysta Oskar Kolberg (1814-1890) w tomie 23 dotyczącym Kaliskiego. Autorka opisuje dokładnie materiały wykorzystywane do budowy przystrojonej trasy i sposób tworzenia wzorów na drodze ${ }^{45}$.

W pracy dyplomowej Joanny Górki z 1999 roku jest zawarta relacji babci autorki. Według niej - odkąd pamiętała (czyli przed drugą wojną światową) strojono już świąteczną drogę, choć była ona dużo krótsza, a zwyczaj ten trwa już ponad 100 lat. $Z$ jej relacji wynika, że tworzono 4 ołtarze oraz 5-6 bram i już kiedy była dziewczynką, droga był ubierana kwiatami. Wówczas za jej dzieciństwa mówiono, że tradycja była stara, wprowadzona przez jakiegoś księdza ${ }^{46}$. Podobną opinię można znaleźć w artykule Lubomira Kosińskiego, który wspomniał, iż na trasie procesji w Sieradzkiem niegdyś symbole roślinne wysypywano piaskiem, tworząc wzory. W Spycimierzu zwyczaj ten rozwinięto, wypełniając wzory rysowane na ziemi płatkami kwiatów. Tradycja ta według niego narodziła się gdzieś u schyłku lat 50. XX wieku. Przypuszczał, że mógł ją wprowadzić jakiś duchowny, który przeniósł ją z Europy południowej ${ }^{47}$.

W artykule Andrzeja Różyckiego podano, iż zwyczaj zdobienia trasy sięga znacznie ponad 100 lat. Autor zaznaczył, że obyczaj ten ewoluuje i rozwija się. W okresie międzywojennym stanowił praktykę sypania piaskiem wzorów na drodze procesji. Po drugiej wojnie światowej zaczęto układać wzory z kwiatów. Przy czym przejściowo jednocześnie sypano piasek i układano kwiaty. Od lat 50. XX wieku dominowały wzory kwietne. Z roku na rok długość trasy wydłużała się, co wiązało się z chęcią bardziej okazałego zaprezentowania się wsi wobec przyjezdnych obserwatorów, których w latach 90. XX wieku było już wielu. Jak przypuszcza autor, również ze względu na tych zewnętrznych odbiorców ceremonia jest przeniesiona na późne popołudnie. W 1994 roku zdobiona trasa liczyła już ponad $1 \mathrm{~km}$. A. Różycki twierdził, że tradycja ta nie jest znana w Polsce ${ }^{48}$.

${ }^{44}$ J. Sobczak, Boże Ciało w Spycimierzu, w: Wielkopolska nasza kraina, t. 3. Rzecz o wybitnych ludziach, kulturze ludowej i turystyce Wielkopolski, red. W. Łęcki, Poznań 2004, s. 122.

${ }^{45}$ M. Klimczak, Stownictwo gwarowe zwiazane z życiem społecznym i obyczajowym we wsi Śpicimierz woj. konińskie, Łódź 1988, mps, s. 123.

${ }^{46}$ J. Górka, Dziedzictwo kulturowe wsi Śpicimierz, Warszawa 1999, mps, s. 37-39.

${ }^{47}$ KP Spycimierz, Zbiór wycinków gazet, L. Kosiński, Kwietne dywany na Boża chwałe, „Gospodyni”, s. 14-15.

${ }^{48}$ Jak już wyżej wspomniano skromne naśladownictwo tego obyczaju miało wówczas miejsce w parafii Piekary i Poddębice. Zob.: A. Różycki, Notatki z podróży po Polsce, „Konteksty Polska Sztuka Ludowa", 48 (1994) nr 3-4, s. 122. 
Dwa kolejne artykuły podają, iż omawiana tradycja istnieje ponad wiek. M. Komajda twierdzi, że według najstarszych mieszkańców tradycja przystrajania drogi liczy ponad 100 lat. Początkowo jedynie jasnym piaskiem wysypywano wzory na drodze. ${ }^{49} \mathrm{~S}$. Nowicki wspomina, że na początku XX wieku parafianie mieli dekorować trasę procesji wzorami sypanymi z żółtego piasku ${ }^{50}$.

Następca ks. W. Krzywańskiego, ks. Maciej Dyoniziak w swojej książce, wydanej w 2004 roku, wspomina, że zwyczaj przyozdabiania trasy procesji sięga ok. 200 lat $^{51}$. W artykule Agnieszki Tomaszczuk podano, iż według najstarszych mieszkańców liczy również blisko 200 lat $^{52}$. W 2007 roku obchodzono nawet 200-lecie zwyczaju układania dywanów kwiatowych ${ }^{53}$.

Sporym utrudnieniem podczas tworzenia kompozycji z kwiatów było do początku XXI wieku przepędzane rano i wieczorem bydło, co wiązało się z koniecznością uprzątnięcia $\mathrm{z}$ trasy wszelkich pozostawionych przez trzodę nieczystości ${ }^{54}$. Dopiero od 12 lat trasa procesji jest wyłożona kostką brukową i asfaltowana (15 czerwca 2006 roku po raz pierwszy trasa była dekorowana na nowym deptaku ${ }^{55}$ ), poprzednio była to droga gruntowa, którą należało polać wodą, utwardzając piaszczystą powierzchnię, by nie tworzyły się podczas przechodzenia tumany kurzu od wysuszonej na niej ziemi.

\section{Podsumowanie}

Najstarszy jak dotąd ustalony przekaz źródłowy dotyczący przystrajania trasy procesji Bożego Ciała w Spycimierzu pochodzi z 1957 roku. Przekazy ustne lokują początki tego zwyczaju gdzieś na przełomie XIX/XX wieku lub też wcześniej na początku XIX wieku. Cezurę tę ks. W. Krzywański wiąże z przeniesieniem podobnych tradycji z innych krajów przez byłych żołnierzy napoleońskich, pochodzących z okolic Spycimierza. Według innych opinii z lat 90. XX wieku tradycję tę mógł zaszczepić miejscowy duchowny przed drugą wojną światową czy też w latach 50. XX wieku. Przekazy są zgodne, że zwyczaj ewoluował i przed drugą wojną światową przede wszystkim sprowadzał się do sypania kompozycji $\mathrm{z}$ jasnego piasku, dopiero później w większym stopniu wykorzystywano kwiaty do ozdobienia trasy procesji. Wpływ na rozwój artystyczny i różnorodność kompozycji trasy miał niewątpliwie od końca lat 70. XX wieku długoletni duszpasterz parafii ks. W. Krzywański, który nadał tej tradycji wymiar medialny.

Zebrane informacje, także te od mieszkańców Spycimierza, wskazują na głęboką lokalną więź, przywiązanie do tradycji i stworzenie unikalnego

\footnotetext{
${ }^{49}$ Komajda, Wieś kwiatami, s. 13.

${ }^{50}$ Nowicki, Boże Ciało, s. 3.

${ }^{51}$ M. Dyoniziak, Boże dywany w Spycimierzu, Bydgoszcz 2004, s. 17.

${ }^{52}$ A. Tomaszczuk, Kwietny kobierzec. O obchodach święta Bożego Ciała w Spycimierzu, „Konteksty Polska Sztuka Ludowa”, 58 (2004) nr 1-2, s. 213.

${ }_{53}$ M. Dyoniziak, Z. Łukasik, Dwa wielkie jubileusze w Spycimierzu, „Uniejowskie Strony”, (2007) nr 3, s. 28.

${ }^{54}$ Wywiad autora z Marią Pełką ze Spycimierza przeprowadzony 17 maja 2017 roku w Uniejo-

${ }^{55}$ T. Wójcik, Dziewięćset lat parafii w Spycimierzu, „W Uniejowie”, (2006) nr 26, s. 8.
} wie. 
mikorkosmosu kulturowego Spycimierza, który z jednej strony definiuje jego mieszkańców, a $\mathrm{z}$ drugiej na uroczystości Bożego Ciała ściąga do niego tłumy zainteresowanych.

W 2016 roku powstało Parafialne Stowarzyszenie Spycimierskie Boże Ciało, które rozpoczęło formalne starania o wpisanie na krajową listę niematerialnego dziedzictwa kulturowego omawianego zjawiska etnograficznego i obrzędu liturgicznego. Jednym $\mathrm{z}$ głównych inicjatorów tej idei był ks. Wojciech Kaźmierczak, proboszcz Parafii Podwyższenia Krzyża Świętego w Spycimierzu. Zabiegi te zakończyły się sukcesem, gdy „Procesja Bożego Ciała z tradycją kwietnych dywanów w Spycimierzu" 14 lutego 2018 roku trafiła na wspomnianą listę ${ }^{56}$.

Z całą pewnością kolejna inicjatywa wprowadzenia omawianego zwyczaju na światową listę dziedzictwa kulturalnego, która powstaje na podstawie Konwencji UNESCO, mieści się w niezwykle wyraźnej tendencji tego, co socjologia, antropologia ale też historia wpisuje w pojęcie małej, lokalnej ojczyzny. Co wyjątkowe, w omawianym przypadku można odnaleźć również konotacje europejskie tej ludowej tradycji.

\section{Źródła}

\section{BIBLIOGRAFIA}

\section{Archiwum Diecezjalne we Wloclawku (ADWl)}

Akta diecezji kujawsko-kaliskiej, Akta wizytacji, sygn. 17 (209).

Prace dyplomowe, sygn. 56, ks. W. Kujawski, Spicimierz, s. 1.

Archiwum Kurii Diecezjalnej we Włocławku, Akta parafii Śpicimierz, sygn. AKDWł par. 203.

\section{Archiwum rodzinne Marii Pełki ze Spycimierza}

Fotografia procesji Bożego Ciała z 1976 r.

\section{Kancelaria parafii rzymsko-katolickiej w Spycimierzu (KP Spycimierz)}

Kronika parafii Spycimierz 1945-1960, k. nlb.

Kronika parafii Spycimierz 1977-1984, 1992-96, k. nlb.

Zbiór wycinków gazet, Lubomir Kosiński, Kwietne dywany na Bożą chwałę, „Gospodyni”, s. 14-15.

\section{Źródła rękopiśmienne}

Górka Joanna, Dziedzictwo kulturowe wsi Śpicimierz, Warszawa 1999, mps.

Klimczak Mirosława, Słownictwo gwarowe związane z życiem społecznym i obyczajowym we wsi Śpicimierz woj. konińskie, Łódź 1988, mps.

Wywiad autora z ks. Wojciechem Krzywańskim przeprowadzony 16 maja 2017 roku we Włocławku- Michelinie.

Wywiad autora z Marią Pełką ze Spycimierza przeprowadzony 17 maja 2017 roku w Uniejowie.

${ }^{56}$ M. Kubacki, Spycimierskie kwietne dywany na krajowej liście dziedzictwa, „W Uniejowie”, (2018) nr 73, s. 3 


\section{Opracowania}

Bogunia-Borowska Małgorzata, O zwyczajach pobożnych. Groby w Wielki Piątek $i$ procesje $w$ Boże Ciało. Antropologia zwyczajów religijnych $w$ społeczeństwie polskim, „Societas Communitas”, 17 (2014) nr 1, s. 217-235.

Chojnacki Krzysztof, Kwietna droga, „Kwietnik”, (1998) nr 6, s. 28-29.

Ciesielska-Szynal Bogna, Dekoracje kwiatowe trasy procesji Bożego Ciała w Spicimierzu, „Sieradzki Rocznik Muzealny”, 10 (1995/1996) s. 31-35.

Dyoniziak Maciej, Boże dywany w Spycimierzu, Bydgoszcz 2004.

Dyoniziak Maciej, Boże Ciało w Spycimierzu - w hołdzie Janowi Pawłowi II, Bydgoszcz 2005.

Dyoniziak Maciej, Łukasik Zbigniew, Dwa wielkie jubileusze w Spycimierzu, „Uniejowskie Strony", (2007) nr 15, s. 28.

Fedorowicz Szymon, Procesje parafialne i klasztorne $w$ oktawie Bożego Ciała $w$ XIXwiecznym Krakowie (1795-1918), „Nasza Przeszłość”, 115-116 (2011) s. 219-243.

Głaz Andrzej, Boże Ciało w Spycimierzu, „Kronika Wielkopolski”, 4 (2005) s. 119-122.

Hołda Renata, Boże Ciało. Święto, ceremonia i performans, ,Journal of Urban Ethnology”, 11 (2013) s. 61-74.

Jabłoński Marek, Z cyklu „,Moja wieś” Spicymierz, „Echo Turku”, (1993) nr 6, s. 6.

Jackowski Jan, Iwanicka Joanna, Dywany w Śpicimierzu, „Gazeta Sołecka”, (1996) nr 10, s. $14-15$.

Kaniecki Krzysztof, Dywany zrywane na miare,, „Dziennik Łódzki”, 8 VI 2007, s. 22.

Kaniecki Krzysztof, Kolorowy Śpicimierz, „Nad Wartą”, (2002) nr 23, s.13.

Klata Hanna, Było - nie minęło. Gawęda o Śpicimierzu, „Ład Boży” dodatek do „Niedziela”, (2000) nr 16, s. 3-4.

Komajda Małgorzata, Wieś kwiatami malowana, „W Uniejowie”, (2000) nr 2, s. 12-13.

Krzywański Wojciech, Boże Ciało w Śpicimierzu, w: Kalendarz Rolników 1994, red. E. Marciniak, Włocławek 1994, s. 93-97.

Kubacki Michał, Spycimierskie kwietne dywany na krajowej liście dziedzictwa, W Uniejowie, (2018) $\mathrm{nr} 73$, s. 3

Kujawski Witold, Śpicimierz, „Ład Boży”, (1992) nr 19, s. 6.

Kwietne dywany na chwatę Panu, „Echo Turku”, (2007) nr 24, s. 3.

Lasociński Dawid, Po kwietnych dywanach, „Turystyka” 20, dodatek do „Turystyka”, (2005) nr 117, s. 7

Maluśkiewicz Piotr, Ziemia konińska. Przewodnik turystyczny, Konin 2002.

Micuła Alicja, Spicimierz. Dywany kwiatowe, „Tele Tydzień”,(2004) nr 23, s. 42.

Nowicki Sebastian, Boże Ciało w Śpicimierzu, „Ład Boży”, dodatek do „Niedziela”, (2000) nr 29, s. 3.

Nowicki Sebastian, Kwietne Boże Ciało, „Ład Boży” dodatek do „Niedziela”, (2001) nr 28 , s. 2.

Po kwiatowych dywanach, „Głos Wielkopolski”, (2001) nr 138, s. 15.

Przybyszewski Wojciech, Procesje Bożego Ciała $w$ Warszawie $w$ latach 1827-1863 $w$ relacjach prasowych, malarstwie $i$ na fotografiach Karola Beyera, „Almanach Warszawy", 9 (2015) s. 203-262.

Radecka Beata, Od ottarza do ottarza po kwietnym kobiercu, „Turystyka”, dodatek do „Turystyka”, (1999) nr 124, s. 6.

Rocznik diecezji włocławskiej 2011, red. A. Niemira, Włocławek 2011.

Różycki Andrzej, Notatki z podróży po Polsce, „Konteksty Polska Sztuka Ludowa”, 48 (1994) nr 3-4, s. 122.

Stownik krajoznawczy Wielkopolski, Warszawa 1992. 
Śmigielska Joanna, Święto Bożego Ciała w Łowiczu, „Societas Communitas”, 2 (2010) s. $255-258$.

Sobczak Jerzy, Boże Ciało w Spycimierzu, w: Wielkopolska nasza kraina, t. 3. Rzecz o wybitnych ludziach, kulturze ludowej i turystyce Wielkopolski, red. W. Łęcki, Poznań 2004, s. 122-123.

Spicimierz. Nie zwykte święto, „Echo Turku”, (1999) nr 24, s. 3.

Tomaszczuk Agnieszka, Kwietny kobierzec. O obchodach święta Bożego Ciała w Spycimierzu, „Konteksty Polska Sztuka Ludowa”, 58 (2004) nr 1-2, s. 213-220.

Uniejowskie strony. Karty z przesztości odleglej, nieznanej i bliskiej gminy Uniejów, red. J. Szymczak, Łódź 2008.

Winnicki Wiesław, Jubileusz OSP w Spycimierzu, „W Uniejowie”, (2008) nr 35, s. 23.

Wójcik Tomasz, Dziewięćset lat parafii w Spycimierzu, „W Uniejowie”, (2006) nr 26, s. 7-8.

Zalewski Zbigniew, Boże Ciało I. Liturgia, w: Encyklopedia katolicka, t. 2, red. F. Gryglewicz, Lublin 1976, kol. 861-862.

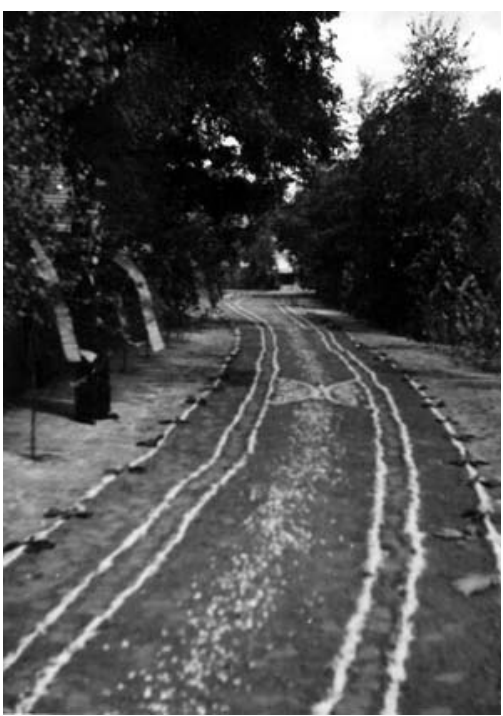

Il.1. Fragment trasy procesji Bożego Ciała w Spycimierzu w 1957 r.

(fot. Archiwum Parafii Spycimierz; Kronika parafii Spycimierz 1945-1960, k. nlb.). 


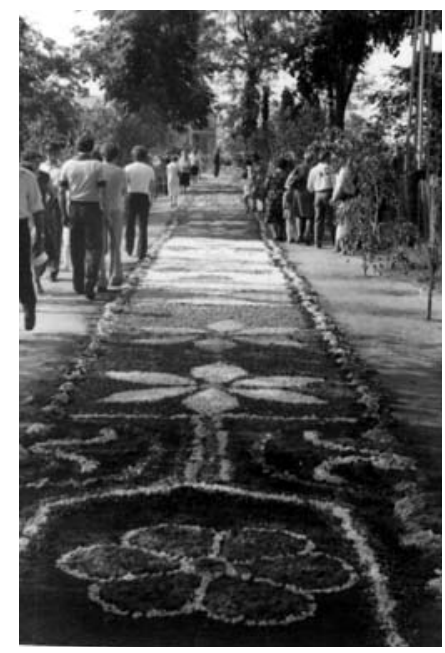

Il.2. Fragment trasy procesji Bożego Ciała w Spycimierzu w 1980 r.

(fot. Archiwum Parafii Spycimierz; Kronika parafii Spycimierz 1977-1984, 1992-96 k. nlb.).

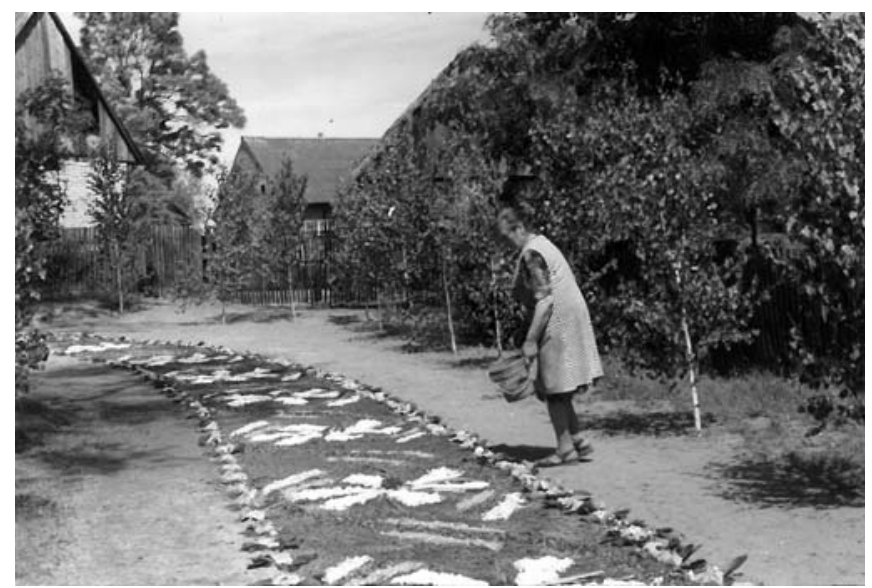

Il.3. Fragment trasy procesji Bożego Ciała w Spycimierzu w latach 1995-1996 (fot. Dział Etnografii Muzeum Okręgowego w Sieradzu). 


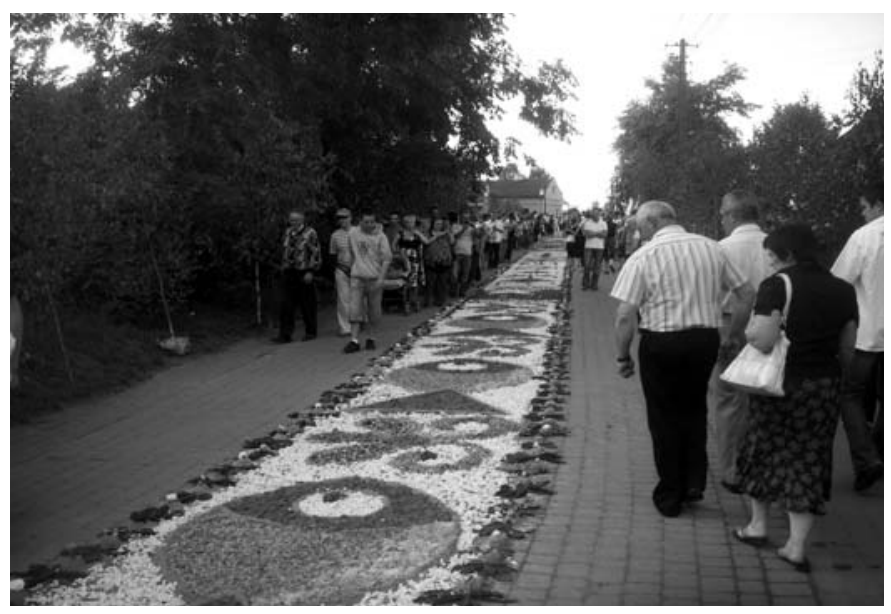

Il.4. Fragment trasy procesji Bożego Ciała w Spycimierzu w 2009 r.

(fot. autora).

\title{
THE BEGINNINGS OF CREATING FLOWER ARRANGEMENTS FOR THE CORPUS CHRISTI PROCESSION IN SPYCIMIERZ
}

\begin{abstract}
Summary
The corpus Christi solemnity initiated in the Catholic Church in the 13th century provided the occasion for the adoration of the Holy Sacrament. In time the solemnity was enriched with the external form of the cult, namely a procession. In the village of Spycimierz, by the River Warta, the adoration of the Host evolved into elaborated visual forms. The route of the Corpus Christi procession, apart from the typically decorated altars, was embellished with flower arrangements, which lay in the mid-lane of the road in the village. According to different accounts, the tradition of creating carpets of flowers dates back to Napoleon's times. It is certain that it existed before World War II, and the first sources informing about it come from 1975.
\end{abstract}

Key words: the history of the Catholic Church; the 13th-21st centuries; Corpus Christi; Spycimierz; processions; folk tradition; floristry 